\title{
Introduction: the working poor in Europe
}

\section{Hans-Jürgen Andreß and Henning Lohmann}

This book is about Europeans who work and are poor. Many people think that the term 'working poor' should be an oxymoron, because nobody who works hard should be poor. Many people also think it is a phenomenon typical for the period of industrialization, as described in Friedrich Engels's seminal work on the 'working class in England' (Engels, 1999) or Benjamin Seebohm Rowntree's study on the 'wage-earning classes in provincial towns' (Rowntree, 2003). Others see it mainly as a problem in the USA, where the situation of the working poor has been a political issue for decades. Just recently, popular books by US journalists like Barbara Ehrenreich (2001) or David K. Shipler (2005) have provided a vivid picture of life at the 'bottom of the working world' in the US economy. In the European context, in-work poverty gained interest only in the late 1990s. The European Councils of Lisbon, Nice and Stockholm highlighted the importance of promoting participation in employment as a means of preventing and alleviating poverty and social exclusion. But recent reports from the European Statistical Office (Eurostat) showed that 7 per cent of the employed population in the EU-15 had an income below the national poverty line (Bardone and Guio, 2005). As a consequence, the European Council stresses in its recent European employment guidelines (EC, 2005) the need to reduce the number of working poor.

But why is in-work poverty back on the European political agenda? Much of the present concern about the working poor has to do with recent changes in labour market policies. High and persistent unemployment in many European countries have led many economists and politicians to believe that creating low-paid and low-skilled jobs will provide the missing job opportunities (European Commission, 2004; OECD, 1994; 2003). In addition, long-term structural changes in the capitalist economy will modify the number and quality of jobs. The change from Fordist to postFordist modes of production is increasing the demand for service sector jobs and flexible labour relations. As a consequence, many scholars expect increasing inequalities within the labour market, with high wages and stable 
work careers on the one side and unfavourable working conditions, low wages, and job instability on the other (Morris and Western, 1999). These structural changes within national economies are enforced by growing economic interdependencies worldwide. In a globalized economy, low-skilled labour in industrialized countries competes with low-skilled labour from less developed countries, which produces similar goods and services at a fraction of the cost (Wood, 1994). This creates a downward pressure on wages for low-skilled labour. Employers, on the other hand, may invest their capital worldwide, and will do so if foreign investments are more profitable. In other words, globalization increases employers' alternatives and thus, their bargaining power. If offshoring is a threat in certain parts of the economy, then employees in these exposed sectors will have to reduce their wage claims (Alderson and Nielsen, 2002; Harrison and Bluestone, 1988).

However, it would be false to blame only the economy for the increase in low-paid jobs. As we already indicated, public policies for the unemployed and the poor have changed as well - partly because former policies have been criticized for not reducing mass unemployment, and partly because of the financial crisis of the welfare state. Benefits have been reduced, and welfare-to-work policies have been implemented in many industrialized countries. Owing to these changes in government policies, work incentives have increased for parts of the inactive population, leading to an increase in the number of workers among those formerly living on welfare or unemployment benefits. Because most of these individuals have no or only lower qualifications, most of them (re)entered the labour market in low-skilled jobs that pay only meagre wages. Furthermore, negative income tax systems or other types of wage subsidies have been introduced which are supposed to make work pay, especially for those already working at the lower end of the wage distribution. In other words, changes in the political system - from welfare to enabling or workfare states (Gilbert, 2002; Jessop, 1993) - have contributed equally well to the increase in low-wage employment.

Finally, it should be noted that the supply of low-paid jobs has also met a certain demand for these kinds of jobs. For example, discriminatory practices in the labour market may leave no other job opportunities available for immigrants. Or flexible working times in the service sector - which are often connected with low-paid jobs - may well be in line with the employment interests of mothers. This does not mean that women or immigrants prefer low pay, but it shows that the increase in low-wage employment cannot be understood without recognizing recent demographic changes (rising female employment, immigration).

But this book is not primarily a book about low pay. Instead, we ask whether gainful employment is sufficient to earn a living - both for oneself 


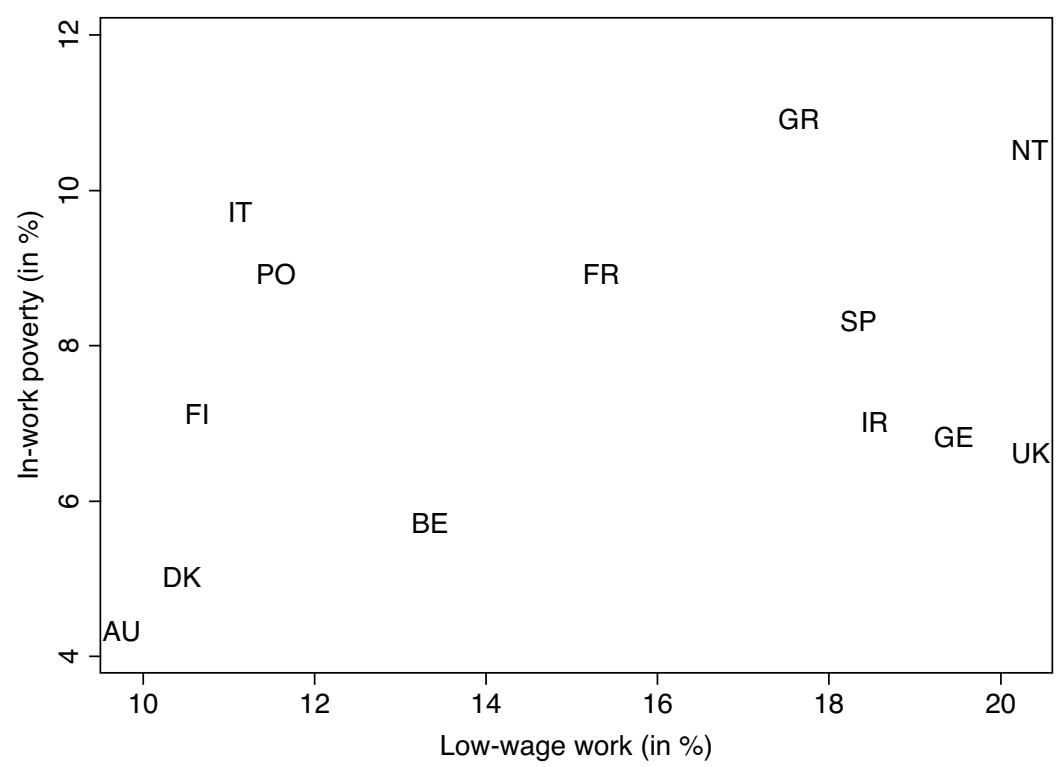

Source: European Community Household Panel 2001, data taken from Chapter 1 by Lohmann and Marx, own computations.

Figure I.1 Low-wage and in-work poverty in selected European countries (2001)

and for one's family members. In answer to that question, low pay is only one among many other explanations. In Figure I.1, we see large variation in in-work poverty as well as in low pay in Europe. However, as the figure shows, low pay and in-work poverty are only modestly correlated. For example, in 2001, we observe countries like Italy with rather high overall poverty rates (in Italy around 11 per cent) that at the same time show a comparatively low percentage of low-wage work (10 per cent in Italy). Similarly, we can find countries with comparatively low overall poverty rates - for example the UK with 7 per cent - in which the incidence of low-wage work is extremely high (20 per cent in the UK).

Many factors contribute to this mismatch, but the main explanation is that low pay is an individual characteristic, while poverty refers to the household. A worker may have a low-paid job, but because he - or more often she - is living with an employed partner, both incomes may lift the household above the poverty line. The same situation applies if labour income is augmented by wage subsidies, family benefits or other sources of non-labour income. In any of these cases, total household income is larger than income from work and thus may well be above the poverty line. 
But, of course, the opposite may happen as well. Consider, for example, a single mother who is working. Depending on the kind of job she holds, her wage may be sufficient for herself, but chances are high that it is inadequate for herself and her children. And we should not forget the workers who have to support a large number of dependent family members. If a second earner is missing, or if the state does not provide cash transfers, the breadwinner together with his or her family members may be poor even if the working person's wage is sufficient for an individual. This is the situation described by Benjamin Seebohm Rowntree at the turn of the twentieth century. He found that wage earners live in poverty during certain phases of their lives - namely, when they are the breadwinners for their families and when they retire from their active working careers (Rowntree, 2003: 137). Although family size has decreased considerably during the past century, large family households still exist - especially in the Southern European countries, where young adults tend to stay with their parents because of high youth unemployment.

Low-wage work (based on personal incomes) and in-work poverty (based on household incomes) do not only differ with respect to the size of both groups but also with respect to their socio-demographic profiles. The most obvious difference is the number of women belonging to each risk group. The high share of women in low-wage work (Asplund and Persson, 2000; Keese et al., 1998) reflects the disadvantageous position of women in the labour market. In-work poverty risks, on the other hand, are quite similar with respect to gender because the risk of poverty is moderated within the household context as we have discussed above. In the following, our main interest is not to regard differences between low-wage workers and working poor, but to explain why the socio-demographic profiles of the working poor differ by country. To answer this question it is necessary to regard the distribution of labour market incomes as well as factors which influence how different sources of income (mainly earnings, partner's income and transfers) are combined within the household.

\section{EXPLAINING IN-WORK POVERTY}

In recent years, several reports have been published on the working poor problem - many at the national level, but few comparative studies (Bardone and Guio, 2005; Marx and Verbist, 1998; Peña-Casas and Latta, 2004; Strengmann-Kuhn, 2003). Most of them are descriptive surveys presenting quantitative information about the incidence and socio-demographic profile of in-work poverty. This book tries to go several steps further. First, it is comparative from the very beginning by providing country reports and crosscountry analyses that follow a similar methodological design (see the next 
section in this chapter). Second, it is descriptive, but it tries to augment the quantitative information with the qualitative background information necessary to understand and put into context each country's national experience with the working poor problem. Finally, we try to provide explanations for why in-work poverty is high in certain countries while low in others.

In thinking about possible explanations, many results from traditional poverty research can be used to interpret different poverty risks within the working population. For instance, it is well known that poverty risks differ with respect to their individual characteristics. One of these is income capacity. Having a university degree or a high school diploma is connected with higher incomes and less poverty. Other risk factors have to do with household characteristics. For example, one labour income will easily feed one single person, while the same labour income may be insufficient for a family with children. Depending on the household situation, some workers will also have to deal with time constraints that restrict their labour supply. For example, if childcare institutions are missing, single mothers will not be able to work full-time, whereas childless, but otherwise identical women are free in their choice of working time. Obviously, the amount of income and, thus, poverty status - depends to a large extent on working time.

Generally speaking, individual and household-related risk factors influence the 'needs' and 'resources' of workers and their family members. These individuals will find themselves in poverty if available resources do not satisfy their needs (see the next section for our operational definition of poverty). But even if one controls for all these risk factors, poverty among the working population is still much higher in some countries than in others. Take, as an example, the analysis on levels of deprivation in Europe by Layte et al. (2001). Although controlling for gender, age, household type, marital status, education, employment status and social class position explains a relevant share of the variation between countries, more than half of the variation remains unexplained. Apparently, the national context is another source of variation. Why is this so? And what are the driving forces behind these country differences? These are the major research questions of this book.

The answers are indicated in the preceding examples. For example, a single mother will more likely search for a full-time job if she can be sure that her children are taken care of in a kindergarten or a full-time day school. Hence, public infrastructure for families supports female employment; this is not only a resource for solo mothers, but also for large families, who are now able to increase their labour supply. Family benefits have already been mentioned. They have been implemented, among other reasons, to ease the lives of single-breadwinner families. Or consider the increase in low-wage jobs in some European countries. As discussed earlier, this is in part a result of new labour market policies (deregulation, 
flexibilization). Similarly, the structure of labour relations has an impact on earnings distribution. Many scholars assume that strong labour unions and centralized wage-bargaining systems decrease the incidence of low pay (for an overview see Flanagan, 1999; Lucifora et al., 2005). The same is assumed for minimum wage legislation and other types of state-enforced wage bargaining. Finally, the amount of public transfers available (welfare payments, unemployment benefits and the like) reduces citizens' reliance on gainful employment (decommodification). Fewer people are forced to work in low-paid jobs. Furthermore, non-working household members are more likely to receive benefits and, hence, to contribute to household income. All these examples demonstrate that the national context - or more specifically, labour market institutions and welfare state provisions - is an additional resource for people of working age. It regulates working conditions, increases bargaining power, supports gainful employment or provides alternative modes of income maintenance. We believe, therefore, that the incidence and socio-demographic profile of the working poor cannot be understood without a thorough understanding of each country's institutional context.

For the moment, we will leave it at these examples. Nevertheless, the institutional explanation could be called the main research hypothesis of this book. Obviously, such a hypothesis cannot be answered without varying the institutional context. Investigating in-work poverty in only one country would not provide the necessary information, because the institutional context within a country is rather constant, at least from a short- or mediumterm perspective. Therefore, our research project had to be comparative from the beginning. The next section explains our methodological approach.

\section{METHODOLOGICAL APPROACH}

Our research combines the case study method with micro-macro analyses. Correspondingly, the following chapters consist of a series of in-depth case studies focusing on single countries combined with comparative analyses of several European countries based on cross-nationally equivalent survey data. The term 'micro-macro analyses' refers to the fact that the later chapters combine micro data on individuals with macro data describing the institutional context.

\section{Comparative Research Design}

But how did we select the countries for our case studies? First, this has been a question of availability. We needed scholars who were both experts on the 
national contexts in question as well as on research in poverty and low pay. Starting from our own research contacts and from our knowledge of the literature, we were able to build a network of interested sociologists, economists and political scientists from nine different European countries. The group met at several workshops, and this book presents the output of our collaborative work.

Furthermore, when building up the research network, we tried to represent different national institutional settings in order to test the validity of our institutional hypothesis. Current research on welfare states usually assumes that there are more or less coherent clusters of institutional arrangements that embody distinct values and rationales. This assumption has been operationalized in the concept of welfare regimes (Arts and Gelissen, 2002; Esping-Andersen, 1990; 1999), and it has been tempting to use one of the existing welfare state typologies to guide our country selection. But many scholars argue that such a typology should be domain-specific (for example, Gallie and Paugam, 2000). Furthermore, very often the internal heterogeneity of these clusters is remarkable which is why many authors regard them only as 'ideal types' (Weber) of the real world. In any case, it is important to specify the institutional arrangements that characterize each cluster and why they influence the phenomenon of interest (in-work poverty in our case). If that work needs to be done anyway, then it is natural to test each characteristic individually.

Although we do not deny the importance of regime typologies as a theoretical tool, we have a preference for the latter approach. This implies a definition of the basic components of the institutional context. What are relevant welfare state regulations and labour market institutions? How can we describe them in general terms? And, finally, how can we measure them empirically? Lohmann and Marx (in this volume) discuss potential relevant institutional factors and how these can be measured. As far as our country selection is concerned, we simply tried to include samples from every region of Western Europe in order to represent the variation in in-work poverty between European countries. We tried to select representatives of each region: Finland and Sweden for the Northern European countries; Ireland and the UK for the Anglo-Saxon countries; Belgium, Germany and the Netherlands for the Central European countries; and Italy for the Southern European countries. Each country chapter provides a descriptive overview of the incidence and socio-demographic profile of the working poor, together with an account of national labour market institutions and welfare state regulations. In doing so, each chapter tries to present a comprehensive picture of in-work poverty in each respective country. Is there a working poor problem? Did it increase over time? What characteristics are 
specific to a given country? And what is a common experience that can also be observed in many other countries?

The single case studies are complemented by two comparative studies including several countries. One of the latter investigates the effect of quantitative measures of the institutional context on poverty status in a sample of workers from 15 European countries. The other evaluates the effect of policies to combat in-work poverty in different European countries. Finally, in a sort of meta-analysis of all the empirical analyses, we try to present some general conclusions concerning the relevance of the working poor problem and the validity of the institutional explanation.

\section{Target Population and Poverty Measures}

Every comparative project is confronted with the question of how to define its central concepts and the population under observation. In our case, the main questions were 'What is poverty?' and 'Who are the workers?' In the case of the first question, we decided to use a concept which - being one of the Laeken indicators - has become a de facto standard at European Union (EU) level. Although poverty is regarded as a multidimensional phenomenon, we only use measures of income as indicators of poverty. Since welfare is determined at the level of households, (net) household income is an appropriate indicator. We use an equivalence scale (modified OECD) to take into account the fact that households differ according to size and composition. In sum, equivalized net household income is the main poverty indicator used in the following analyses. Following on the idea that poverty is a relative concept, we define the poverty line as a fraction of the average income in a given country. Again, we take the respective Laeken indicator as a reference and define the poverty threshold at 60 per cent of the median of national equivalized net household income. This definition is the standard which is used in all chapters. In addition, some of the chapters include other poverty measures - either other indicators (for example, consensual deprivation) or other thresholds (for example, 40 per cent or 50 per cent of the median).

With respect to the second question, we tried to follow the criteria of the International Labour Organization (ILO) wherever possible. Hence, people who work at least one hour per week are regarded as workers. People looking for work are regarded as unemployed, given that they are in a position to take up employment within two weeks. All other people are defined as inactive. Unpaid family members are regarded as self-employed workers. Since we do not want to consider people who are younger or older than what is usually considered a 'working age', we tried to restrict the analyses to the age group between 15 and 64 years. Given that the data used in the 
following analyses do not come from a single source, we had to relax the criteria in some cases. Sometimes the data only includes persons from 17 or 20 years of age onwards. Sometimes no exact information on working hours is included. And sometimes the observation period is not the current week of the interview but the year before data collection, which makes it impossible to categorize workers on the basis of hours worked per week. In that case, employment status is defined on the basis of the number of months a person worked in the past year. Here, persons who worked for at least seven months are regarded as workers.

Combining the definition of poverty and worker we arrive at our definition of the working poor. A working poor individual is a working person who lives in a poor household - that is, a household with an income below the threshold we defined above. Given the variety of the data used in this book, however, it is impossible to give an exact overall description of all the country-specific operationalizations. Discrepancies from our basic definitions will be noted in each chapter.

\section{ORIENTATION OF THE CHAPTERS}

The structure of the volume reflects the basic idea of drawing a broad yet detailed picture of in-work poverty in Europe. The two chapters of Part I provide a basic orientation about the incidence, structure and causes of inwork poverty in Western Europe. The main question addressed in this part is this: is there variation by country, and which institutional and economic factors can be assumed to play a vital role in explaining such variation? Part II is a collection of in-depth country studies. The main question of these chapters is: what characteristics are specific to a given country? Therefore, the empirical analysis of in-work poverty is embedded in a discussion of the institutional and economic framework of each country. Part III combines the comparative and national perspectives and discusses policy options to increase overall employment while minimizing poverty risks of the working population.

Chapter 1, by Henning Lohmann and Ive Marx, examines in-work poverty from a perspective of welfare regimes. The purpose of this paper is to highlight the fact that 'poverty in work' comes in many different guises across advanced welfare states. The claim of the chapter is that the incidence as well as the composition of the working poor differs substantially between welfare regimes. The chapter starts with a broad overview of the differing social, economic and political conditions for in-work poverty, providing information on indicators such as replacement rates, social expenditure, childcare coverage, minimum wage levels, bargaining centralization, 
employment rates and employment shares by sector. Lohmann and Marx discuss how in-work poverty is shaped by the institutional particularities of each welfare cluster and they provide a basic empirical analysis of such differences, which shows that the differences between welfare regimes are less pronounced than expected.

Chapter 2 is aimed at explaining such differences from a micro-macro perspective. Using a multilevel framework, Henning Lohmann analyses the influence of individual or household-related factors and institutional factors on in-work poverty as well as the interaction between the two. The chapter hypothesizes that not only the design of labour market institutions or in-work benefit schemes alters a worker's risk of being poor, but that the general degree of decommodification and defamilization also plays an important role. Transfers paid to non-working household members and services aimed at dual earnership are expected to increase household incomes, and therefore to lower the risk of in-work poverty.

The order of the country studies in Part II is loosely structured by region which - as in many other studies - mirrors quite well the affiliation of each country to an Esping-Andersen-style welfare regime typology. We look at three continental European countries (Belgium, Germany and the Netherlands), two Northern countries (Sweden and Finland), two AngloSaxon countries (the UK and Ireland) and Italy as a Southern European representative. Each of the chapters analyses the situation of in-work poverty in the given country in a broader context. Taken together, the selection of cases provides a picture of in-work poverty in times of welfare state reform and changing economic conditions.

Chapter 3 examines the Belgian case. Ive Marx and Gerlinde Verbist argue that on the surface, Belgium appears to epitomize the archetypal continental European welfare state caught in a 'welfare without work' conundrum. At the same time, however, childcare provisions for working parents are extensive, making Belgium a case in point of what has been called 'optional familialism' (Leitner, 2003), where families caring for children at home are supported, but at the same time families are also given the option of being unburdened from care responsibilities. In addition, over the past decades, Belgium has deployed a wide range of measures to improve the disposable income situation of single-earner households with low incomes as well as to boost multi-earnership. In their empirical analysis, the authors show that in-work poverty in Belgium - as elsewhere on the Continent - is principally a problem of single-parent households and single-earner couples with children. This may come as something of a surprise given the extent to which the breadwinner model is institutionally supported and protected in Belgium, especially if there are children. 
Chapter 4 starts off by presenting an almost classical paradox in the analysis of in-work poverty, namely, that high levels of low-paid employment do not necessarily result in high levels of in-work poverty. Marco Gießelmann and Henning Lohmann show that exactly this is the case in Germany - at least in West Germany. The authors describe the region as an example of the modified male-breadwinner model where a majority of (female) low-paid workers live together with (male) main earners. In East Germany, however, owing to its differing heritage of a dual-breadwinner model and more difficult economic conditions, the link between low-paid work and in-work poverty is much closer. Furthermore, the chapter discusses how recent German welfare state reforms are likely to alter the dominant earner model and the relationship of low-paid work and in-work poverty throughout Germany.

The question of the consequences of welfare state reform on in-work poverty is also the focus of the analysis of the Netherlands (Chapter 5). Erik Snel, Jan de Boom and Godfried Engbersen see the Netherlands as a continental forerunner of an 'enabling state' (Gilbert, 2002), which puts more emphasis on integration via employment than via social rights. Based on this discussion, they ask whether the 'Dutch miracle' of employment growth has been accompanied by an increase of in-work poverty. In addition to institutional change, the analysis looks at economic and demographic factors as potential causes for the growth of in-work poverty.

In Chapter 6, Björn Halleröd and Daniel Larsson analyse changes in inwork poverty in Sweden since the late 1980s. The fact that economic and labour market conditions have changed severely during this period - a shift from demand to supply-side policies and a harsh recession in the early 1990s followed by economic growth - makes Sweden a suitable candidate for analysing the influence of economic factors on in-work poverty. The authors' empirical focus is on the increase of insecure employment and how this is related to in-work poverty. They show that Sweden is still characterized by low levels of in-work poverty (as one would expect in the prime example of a Northern welfare state), but that the rise in the level of unemployment compared to the 1980 s also has consequences for those who are working.

Chapter 7 provides analyses of poverty among working people in Finland from the mid-1990s until 2005. Ilpo Airio, Susan Kuivalainen and Mikko Niemelä describe the main features of the Finnish welfare state and its labour market institutions. Regarding the changes during the past ten years, it appears that changes in the labour market and in welfare state provisions during the end of the 1990s and early 2000s do not give us reason to expect a dramatic increase in in-work poverty, since there are no signs of radical welfare state retrenchment or labour market decentralization. In 
fact, the development of income poverty among working people has been rather constant. In addition, the authors apply an alternative method of measuring poverty. Using this measure, the situation is even more positive - consensual deprivation decreased during the research period. Thus, the overall picture is such that in-work poverty is relatively low in Finland.

Chapter 8, by Ferruccio Biolcati-Rinaldi and Federico Podestà, deals with the Italian case, which is interesting not only as classical example of Southern European welfare regimes, but also because of the high level of internal heterogeneity. Southern Italy, the Mezzogiorno, experiences poverty and in-work poverty incidences much higher than those in the Northern and Central regions. This situation provides the chance to conduct comparative analyses controlling for different economic conditions, family models and welfare supply at the local level. The general hypothesis of this chapter is that the traditional male breadwinner model that sustained Italian economic development from the end of the Second World War to the beginning of the 1970s has become dysfunctional since it produces, among other things, high levels of in-work poverty. Such a crisis calls for new assets which, at the moment, are being provided more successfully in North-Central Italy than in the Mezzogiorno.

Chapter 9, by Sara Connolly, focuses on the question of whether policies such as earned income tax credits and minimum wages, which have been introduced or extended in the UK during the years of the Labour government, have resulted in a reduction in in-work poverty. The results of the empirical analysis do not support such a conclusion. While the situation of families has, in fact, improved, other groups such as singles face an increased risk of in-work poverty.

Ireland is a case which combines the fact of an unprecedented economic boom and growth in employment with an increasing number of working poor - at least if one focuses on standard income poverty measures. In Chapter 10, Brian Nolan argues that one reason why economic development does not translate into decreasing in-work poverty rates is that the rapid growth in living standards is only poorly reflected in conventional poverty measures. What is - irrespective of the measure used - most distinctive about the households of the working poor is how few of their working-age adult members are actually working. Hence, the chapter concludes that in order to be effective in addressing in-work poverty, policy should focus not only on raising the take-home pay of the low paid, but also on the position of households where more of the adults could be in work.

Part III combines the comparative and national perspectives of Part I and II. Chapter 11, by Ive Marx and Gerlinde Verbist, discusses policy options for fighting in-work poverty. Since they see in-work poverty in 
Europe, especially in continental Europe, to a large extent as a problem of underemployment within households, they focus on policies that will boost labour participation rates and thus multi-earnership. They discuss demand-side as well as supply-side measures, including those two policy instruments - minimum wages and in-work benefits - that dominate the current public and policy discourse.

In the final Chapter 12 we will summarize the findings of the eight country and the two comparative analyses. Starting with a recapitulation of the main institutional features of the countries represented in this volume, we attempt to draw some general conclusions on the level and structure of in-work poverty as it is typical under different institutional settings. We conclude with a discussion of the development of in-work poverty over time and whether there is a trade-off between low in-work poverty and employment growth.

\section{REFERENCES}

Alderson, A.S. and F. Nielsen (2002), 'Globalization and the great u-turn: income inequality trends in 16 OECD countries', American Journal of Sociology, 107 (5), 1244-99.

Arts, W. and J. Gelissen (2002), 'Three worlds of welfare capitalism or more? A state-of-the-art report', Journal of European Social Policy, 12 (2), 137-58.

Asplund, R. and I. Persson (2000), 'Low pay - a special affliction of women', in M. Gregory, S. Wiemer and S. Bazen (eds), Labour Market Inequalities: Problems and Policies of Low-Wage Employment in International Perspective, Oxford: Oxford University Press, pp. 53-81.

Bardone, L. and A.-C. Guio (2005), 'In-work poverty. New commonly agreed indicators at the EU level', Statistics in Focus, 5/2005.

Ehrenreich, B. (2001), Nickel and Dimed: On (Not) Getting By in America, New York: Henry Holt.

Engels, F. (1999), The Condition of the Working-Class in England in 1844, Oxford: Oxford University Press.

Esping-Andersen, G. (1990), The Three Worlds of Welfare Capitalism, Cambridge: Polity Press.

Esping-Andersen, G. (1999), Social Foundations of Postindustrial Economies, Oxford: Oxford University Press.

European Commission (2004), Employment in Europe 2004. Recent Trends and Prospects, Luxembourg: Office for Official Publications of the EC.

European Council (EC) (2005), 'Council decision of 12 July 2005 on guidelines for the employment policies of the member states', Official Journal of the European Union, L 205/21.

Flanagan, R.J. (1999), 'Macroeconomic performance and collective bargaining: an international perspective', Journal of Economic Literature, 37, 1150-75.

Gallie, D. and S. Paugam (2000), 'The experience of unemployment in Europe: the debate', in D. Gallie and S. Paugam (ed.), Welfare Regimes and the Experience of Unemployment in Europe, Oxford: Oxford University Press, pp. 1-22. 
Gilbert, N. (2002), Transformation of the Welfare State. The Silent Surrender of Public Responsibility, Oxford: Oxford University Press.

Harrison, B. and B. Bluestone (1988), The Great U-Turn, New York: Basic Books.

Jessop, B. (1993), 'Towards a Schumpetrian workfare state? Preliminary remarks on post-Fordist political economy', Studies in Political Economy, 40, 7-39.

Keese, M., A. Puymoyen and P. Swaim (1998), 'The incidence and dynamics of lowpaid employment in OECD countries', in R. Asplund, P.J. Sloane and I. Theodossiou (eds), Low Pay and Earnings Mobility in Europe, Cheltenham: Edward Elgar, pp. 223-65.

Layte, R., C.T. Whelan, B. Maître and B. Nolan (2001), 'Explaining levels of deprivation in the European Union', Acta Sociologica, 44 (2), 105-22.

Leitner, S. (2003), 'Varieties of familialism. The caring function of the family in comparative perspective', European Societies, 5 (4), 353-75.

Lucifora, C., A. McKnight and W. Salverda (2005), 'Low-wage employment in Europe: a review of the evidence', Socio-Economic Review, 3, 259-92.

Marx, I. and G. Verbist (1998), 'Low-paid work and poverty: a cross-country perspective', in S. Bazen, M. Gregory and W. Salverda (eds), Low-Wage Employment in Europe, Cheltenham: Edward Elgar, pp. 63-86.

Morris, M. and B. Western (1999), 'Inequality in earnings at the close of the twentieth century', Annual Review of Sociology, 25, 623-57.

Organisation for Economic Co-operation and Development (OECD) (1994), The OECD Jobs Study. Evidence and Explanations (Part I-Labour Market Trends and Underlying Forces of Change), Paris: OECD.

Organisation for Economic Co-operation and Development (OECD) (2003), Employment Outlook, Paris: OECD.

Peña-Casas, R. and M. Latta (2004), Working Poor in the European Union, Luxembourg: European Foundation for the Improvement of Living and Working Conditions.

Rowntree, B.S. (2003), Poverty - A Study of Town Life, Basingstoke: Palgrave Macmillan.

Shipler, D.K. (2005), The Working Poor: Invisible in America, New York: Vintage Books.

Strengmann-Kuhn, W. (2003), Armut trotz Erwerbstätigkeit. Analysen und sozialpolitische Konsequenzen, Frankfurt and New York: Campus.

Wood, A. (1994), North-South Trade, Employment and Inequality: Changing Fortunes in a Skill-Driven World, Oxford: Oxford University Press. 